\title{
RECOMMENDATIONS FOR SPACE REACTOR R\&D TASKS
}

\author{
Robert L. Wiley \\ Consultant \\ 5998 Camelback Lane \\ Columbia, MD 21045 \\ (410) $730-4630$
}

\author{
Albert C. Marshall \\ Sandia National Laboratories \\ P.O. Box 5800 \\ Albuquerque, NM 87185 \\ (505) $844-4903$
}

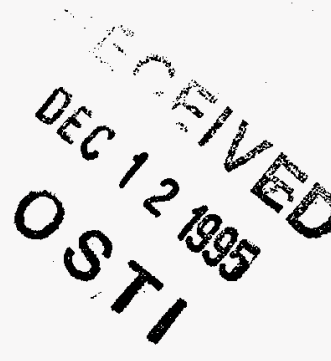

\begin{abstract}
A rationale was developed to determine which technologies a space nuclear reactor technology base program should pursue based on the fact that budgets would be limited. A preliminary evaluation was conducted to identify key technical issues and to recommend a prioritized set of candidate research projects that could be undertaken as part of the Defense Nuclear Agency (DNA) program in the near term. The recommendations made have not been adopted formally by the DNA's Topaz International Program (TIP), but serve as inputs to the program planning process.
\end{abstract}

\section{INTRODUCTION}

Effective in FY 1996, DNA has assumed responsibility for the TIP from the Ballistic Missile Defense Organization (BMDO). Due to funding limitations, BMDO canceled its planned flight demonstration of nuclear electric propulsion using an existing Russian Topaz II reactor. DNA is in the process of redirecting the TIP toward broader-based R\&D effort that will clearly establish the technical readiness of critical components and technologies.

In order to develop a strategy for space reactor technology development, DNA sponsored a brief review of potential national needs that may be addressed by space reactor systems. A systematic approach was used to explore needs at several levels (Marshall and Wiley 1996). Using the findings of this review, a rationale was developed to focus on research areas that can be developed at reasonable cost. A preliminary evaluation was conducted to identify key technical issues and provide a prioritized set of candidate research projects to be undertaken as part of the DNA program.

\section{RATIONALE FOR R\&D RECOMMENDATIONS}

Obviously, the R\&D necessary to establish technical readiness of many systems far exceeds any anticipated funding possibilities. Hence, budget constraints limit the scope to addressing technical issues for only a few space reactor systems. Furthermore, a rationale must be established for prioritizing the systems and technologies addressed by the R\&D in order to prevent the TIP from becoming a technology sandbox wherein everyone's favorite idea is included, but the work on any one is insufficient to meet the objective.

Inherent in the overall objective is the need to reduce the development time for the first flight system so that when a potential mission is identified, a satisfactory reactor system can be available in a time frame consistent with the timing of the mission. A ten year development program is unacceptable. Five years or less is a reasonable target, but to achieve this capability, future designers will need established phenomenology and performance databases, including design margins, and validated life prediction models. With the objective of being able to catch a future mission window, the following guidelines were used to help determine R\&D priorities: 


\section{DISCLAMMER}

Portions of this document may be illegible in electronic image products. Images are produced from the best available original document. 
- Focus on a first generation power need of tens of kilowatts and potentially long life;

- Work on resolving fundamental issues, not near-term engineering problems;

- Work on the long-pole issues (e.g., lifetime) that take years to resolve;

- Focus on testing and validation of models, not on system design and analysis;

- Focus on problems for systems/subsystems that are reasonably well known; and

- Focus on defining the capabilities of near-term system technologies

(as opposed to meeting a perceived requirement threshold).

The next issue is deciding which systems and technologies to emphasize. R\&D priority decisions are complicated by the fact that the predicted performance of a concept and its components almost always exceeds actual performance of the hardware when tested. Furthermore, the learning curve that accompanies any system development invariably uncovers technical issues that were not apparent at the conceptual level. Many concepts are based on technologies successfully developed in the 1960s, but experience has shown that recovering this capability can be costly and time consuming. As a consequence, emphasis is given to systems for which the current technical understanding is best established.

In order to recommend specific work, key issues are identified, and priority R\&D tasks are identified that could be initiated in FY 1996. The focus is on FY 1996 because of the urgency of identifying and initiating specific $R \& D$ projects. A broader multiyear roadmap must still be developed. This roadmap must be accompanied by budget projections, metrics for evaluating $R \& D$ results, and decision criteria for continuation or termination of specific projects.

The recommended tasks are not listed in order of priority, but are instead grouped into priority 1 and 2 categories. The basis for priority 1 is primarily funding limits rather than technical importance; for example, most of the tasks involving in-core testing are relegated to priority 2.

\section{RECOMMENDED TASKS FOR FY 1996}

Based on the recommendations in the companion paper (Marshall and Wiley 1996) and the considerations outlined above, emphasis is placed on three system types: (1) the current TIP in-core thermionic technology, (2) systems based on the SP-100 reactor, and (3) cermet core thermal propulsion technology. In addition, several technical areas (instrumentation and control, heat transport and rejection) are relatively generic in that the $R \& D$ can be applied to a variety of system configurations.

\section{In-core Thermionics}

The likelihood of success for an in-core thermionic system can be greatly enhanced by the availability of Russian expertise and experience. However, since Russian designs are based on relatively short mission durations, technical issues related to lifetime dominate the thermionic tasks. The major technical issues are:

- Fuel swelling/emitter deformation;

- CVD W and monocrystal Mo-Nb alloy creep strength/stability;

- Fission gas venting;

- Insulator/spacer life (Cs exposure, combined temperature/voltage/radiation effects);

- Interelectrode gap kinetics (Cs, surfaces, contamination);

- Cs pressure/purity control;

- Seal leak rate/life (temperature, radiation, Cs); and

- TFE fabrication cost. 
Several of these issues were addressed but not fully resolved during the U.S. Thermionic Fuel Element Verification Program (General Atomics 1994). Priority task recommendations for the TIP in FY 1996 are as follows:

Priority 1:

Continue modeling/empirical investigation of $\mathrm{Cs}$ effects on insulators;

Initiate modeling/parametric testing of gap contamination $\left(\mathrm{H}_{2}\right.$, graphite, fission gases);

Continue IPPE in-core test on $\mathrm{Al}_{2} \mathrm{O}_{3}$ insulator samples;

Expand database on monocrystal Mo-6Nb creep strength (biaxial tests); and

Investigate microstructure stability of monocrystal Mo-6Nb.

Priority 2:

Initiate in-core fission gas venting test in Russia (fueled emitter or SC-320 TFE);

Initiate parametric in-core Topaz II fuel/monocrystal Mo-6Nb clad swelling tests;

Determine thermionic cell performance sensitivity to Cs pressure/purity levels;

Design and life test Cs pool reservoir to control pressure/purity; and

In-core testing of trilayer seals; measure hot leak rates.

\section{Moderator}

For the initial anticipated power level of a few tens of kilowatts, the minimum mass in-core thermionic systems are moderated. The Russians successfully used $\mathrm{ZrH}_{\mathrm{x}}$ encased in stainless steel, but again for one- to two-year lifetimes. If the temperature is controlled, $\mathrm{ZrH}$ may be acceptable for ten years, or a lower vapor pressure material like $\mathrm{YH}_{\mathrm{X}}$ may be preferable. The issues to be addressed are as follows:

- Hydrogen loss rate vs. temperature $\left(\mathrm{ZrH}_{\mathrm{x}}, \mathrm{YH}_{\mathrm{x}}\right)$; and

- Containment material and coatings/permeation rate (SS, Be).

Recommended tasks for FY 1996 are:

Priority 1:

Complete post irradiation examination on irradiated $\mathrm{YH}_{1.75} / \mathrm{Be}$ sample at $\mathrm{LUTCH}$.

Priority 2:

Conduct $\mathrm{H}_{2}$ permeation tests on Russian $\mathrm{ZrH}_{\mathrm{x}} / \mathrm{SS}$ samples; and

Develop life model of Russian $\mathrm{ZrH}_{\mathrm{x}} / \mathrm{SS}$ moderator system.

\section{NaK Loop Heat Transport System}

Most recently, NaK loops for reactor cooling have been applied to in-core thermionic systems. However, the same technology can be applied to alternative configurations, such as a moderate temperature core using stainless steel or superalloy cladding. Since a heat transport loop is vulnerable to a single-point failure, reliability and lifetime are of particular importance. The main issues are:

- Long-term performance of NaK loop;

- Long term DC electromagnetic pump performance;

- Hydrogen removal (source may be the moderator or bimodal operation); and

- Thin-wall stainless steel corrosion (with and without titanium alloys in radiator).

Priority task recommendations for the TIP in FY 1996 are as follows: 
Priority 1:

Test $\mathrm{H}_{2}$ gettering capability of $\mathrm{Y}, \mathrm{YH}$;

Investigate SS and SS/Ti corrosion; quantify required purity levels for lifetime; and

Evaluate establishment of NaK loop test facility.

Priority 2:

Compile data from Russian pump design and test experience; and

Initiate pump life test.

\section{Lithium Loop Heat Transport System}

During the SP-100 program, significant progress was made on this subsystem, and a critical database on reactor material compatibility was established (Mondt and Truscello 1994). In addition, Energia has proposed a thermionic system using $\mathrm{Li}$ cooling. However, as with a NaK loop, a $\mathrm{Li}$ loop is vulnerable to a single-point failure, and reliability and lifetime have not been demonstrated. The main issues to be addressed are:

- Long-term performance of Li loop;

- Performance/life of gas separator/accumulator to remove He from Li;

- Development of prototypic thermoelectromagnetic (TEM) pump; and

- Long term TEM pump performance.

Specific recommendations for FY 1996 are:

Priority 1:

Investigate Energia work on Li loop design and testing; and

Evaluate establishment of Li loop test facility.

Priority 2:

Gas separator/accumulator screen life test in $\mathrm{Li} / \mathrm{He}$ at operating temperature; and

Fabricate a "lessons-learned" pump and test with Li.

\section{Conductively-coupled Thermoelectrics}

A major issue still facing the SP-100 system is development of the conductively-coupled thermoelectric cells and modules (Mondt and Truscello1994). Promising results are being obtained in life tests of individual cells; however, cell internal resistance remains higher than desired, and the standard SiGe material (developed under RTG programs) is still being used instead of improved SiGe that has been under development by NASA. The specific technical issues related to the converter are:

- Stability of $\mathrm{Si}_{3} \mathrm{~N}_{4} /$ glass perimeter seal around graphite-to-SiGe bond;

- High contact resistance at graphite-to-SiGe (MoGe) bond;

- Development of higher figure of merit (Z) SiGe;

- Low cell fabrication yield;

- Fabrication of thermoelectric converter assembly ( $4 \times 6$ or $6 \times 10$ cells/assembly); and

- Fabrication cost.

If the TIP broadens its focus to continue thermoelectric development, the priority tasks recommended in $\mathrm{FY} 1996$ are as follows:

Priority 1:

Initiate in-gradient tests of new cells \#155 and \#158; 
Continue in-gradient cell tests;

- \#150 at Lockheed Martin (test covered by DOE through FY 1996);

- \#139 and \#148 at JPL (test covered by JPL through FY 1996);

Continue work on reducing MoGe bond resistance (pending DOE results in FY 1995);

- Addition of dopants to MoGe;

- Annealing process to reduce pores in bond; and

Measure time-temperature properties of current state of improved $n$ and $p \mathrm{SiGe}$.

Priority 2:

Finalize processes for converter assembly fabrication; demonstrate scale-up;

Investigate fabrication yield improvement;

- Determine time-temperature annealing process to reduce p-type fractures;

- Develop alternative glass compositions for toughness and CTE match;

- Develop alternative barrier graphite (CTE match) for SiGe/graphite/W joint; and

- Optimize processing and braze material for hot side compliant pad bond.

\section{Instrumentation and Control}

Instrumentation and control (I\&C) is an area that has been somewhat neglected in many system designs, primarily because either other issues were considered more important or design solutions to $1 \& \mathrm{C}$ problems were identified or assumed. The most detailed recent work was done as part of the SP-100 program (Mondt and Truscello 1994), but the focus of the work was control drives (for which problems still exist). The $1 \& C$ issues that need to be addressed are as follows:

- Lubricant life/temperature limits;

- Drive assembly life > 3 years;

- Long life instrumentation;

-- Neutron detector;

-- Thermocouples/Johnson Noise Thermometer;

- Position sensor;

-- Pressure transducer;

-. Flow rate sensor; and

- Rad-hard control electronics.

Recommendations for TIP work in FY 1996 are:

Priority 1:

Measure $\mathrm{MoS}_{2}$ lubricant sublimation rates at $700 \mathrm{~K}, 811 \mathrm{~K}$, and $1000 \mathrm{~K}$; and

Determine temperature/life limits of $\mathrm{HfO}_{2}$ (and $\mathrm{HfC}$ ?) coating on $\mathrm{Nb}-1 \mathrm{Zr}$.

Priority 2:

Investigate dry lubricant alternatives to $\mathrm{MoS}_{2}\left(\mathrm{Cr}_{2} \mathrm{O}_{3}\right.$, diamond);

Determine operational problems with SP-100 control drive assembly (CDA) actuator;

Rework CDA actuator and conduct subassembly life tests at $700 \mathrm{~K}, 811 \mathrm{~K}$ (and higher?);

Measure neutron degradation/annealing of JFET (2N5911); and

Irradiation life testing of sensors.

\section{Thermal Propulsion}

For thermal propulsion (or bimodal power and propulsion), the key issue is the nuclear fuel form and its operation in a very high temperature hydrogen environment. A cermet-type fuel 
is judged to be the leading candidate by the nuclear bimodal study team, although for propulsion only (as opposed to bimodal), other concepts, e.g., the particle bed, warrant additional evaluation.

Unfortunately, fuel development is expensive, and the level of sustained funding required is beyond what DNA will be able to support. Fabrication and long-term integrity of $\mathrm{UO}_{2}$ and UN fuels are relatively well established, although some issues remain, but recent experience with propulsion fuels and fuel elements is very limited. Hence, development of a suitable propulsion fuel is a major effort. As a result, no $R \& D$ on propulsion fuels is recommended in FY 1996. If additional funds become available, this conclusion should be revisited. However, a survey to determine the state of the art of Russian propulsion fuel technology would be beneficial for subsequent DNA planning and is recommended for FY 1996. The results may identify future $R \& D$ that would be of mutual benefit to both countries.

\section{Other Technical Areas of Interest}

Obviously, several other technical areas deserve attention. Notable examples are liquid metal heat pipes, light-weight radiators, alternative power conversion (Brayton, AMTEC, out-ofcore thermionic), and thermal propulsion fuels. Some of these are included in other programs, and some may be addressed in the future during the course of the DNA program.

\section{CONCLUSION}

The decision rationale and tasks identified in this study form a basis for further expanding the R\&D work in the TIP in a way that will satisfy the DNA objective for the program. These tasks address the long poles for the systems that are the most developed and best understood. The priority 1 tasks are intended to provide significant progress within a severely constrained budget. If funds are available, priority 2 tasks should be initiated to the degree possible. Future TIP R\&D tasks should be prioritized on the basis of the results of ongoing R\&D, within both the TIP and other programs. The recommendations made have not been adopted formally by the DNA's TIP but serve as inputs to the program planning process.

\section{Acknowledgments}

This work was sponsored by BMDO through the Topaz International Program at Phillips Laboratory. Mr. Wiley's consulting work was conducted under Work Order F29650-95WO529. Mr. Marshall is employed by Sandia National Laboratories under contract DE-AC0494AL85000. Several individuals volunteered their time to provide assistance and advice during the study, notably Ned Britt, Kent Koester, Al Josloff, Dick Morgan, Val Raag, Jack Mondt, Gerry Stapher, Jan Vandersande, and Ed Storms.

\section{References}

General Atomics (1994) "Thermionic Fuel Element Performance Final Test Report - TFE Verification Program," (June 1994) GA-A21596, San Diego, CA.

Marshall, Albert C., and Robert L. Wiley (1996) "An assessment of Space Reactor Technology and Recommendations for Development," in Proceedings of the Space Technology and Applications International Forum (STAIF-96), Prof. Mohamed El-Genk, Conf-96-0109, January $7-11,1996$, AlP Conference Proceedings No. TBD.

Mondt, Jack F. and Vincent C. Truscello (1994) "SP-100 Technical Summary Report," (September 1994) JPL D-11818, Jet Propulsion Laboratory, Pasadena, CA. 


\section{DISCLAIMER}

This report was prepared as an account of work sponsored by an agency of the United States Goverament. Neither the United States Government nor any agency thereof, nor any of their employees, makes any warranty, express or implied, or assumes any legal liability or responsibility for the accuracy, completeness, or usefulness of any information, apparatus, product, or process disclosed, or represents that its use would not infringe privately owned rights. Reference herein to any specific commercial product, process, or service by trade name, trademark, manufacturer, or otherwise does not necessarily constitute or imply its endorsement, recommendation, or favoring by the United States Government or any agency thereof. The views and opinions of authors expressed herein do not necessarily state or reflect those of the United States Government or any agency thereof. 